\title{
Religião: autonomia, especificidade ou subordinação? Reflexões sobre a História das Religióes a partir da Reforma Protestante
}

\author{
João Guilherme Lisbôa Rangel*
}

\begin{abstract}
RESUMO
A partir da análise de diferentes abordagens acerca da relação entre História e religião, bem como sobre a História das Religiões, o presente artigo reflete até que ponto se pode considerar a religião como categoria autônoma e específica do conhecimento. Em outras palavras, procura-se pensar até que ponto o religioso apresenta certa especificidade epistemológica ou então se ela se submete ao arbítrio da cultura. No que compete a disciplina História, a religião estaria desconectada ou subordinada à História Cultural? Para ilustrar tal embate e suas aplicações, recorre-se ao caso da Reforma a fim de verificar como a dimensão do religioso, especificamente a iconoclastia da Reforma, foi abordada pela historiografia e os impactos interpretativos das diferentes concepções sobre a religião neste acontecimento.
\end{abstract}

Palavras-chave: Religião. Cultura. História. Reforma. Iconoclastia.

\section{Religion: autonomous, specific or subjected field of study? Reflections on the History of Religions drawn upon the Protestant Reformation}

\begin{abstract}
Based on analyses regarding different approaches to the relationship between history and religion, the present study aims to comprehend to what extent religion can be considered an autonomous and specific field of study, i.e., we seek to investigate whether religion has a specific epistemology or if it should be under the scope of culture. By considering history a discipline, is religion disconnected or subjected to Cultural History? To illustrate such dillema its possible ramifications, we draw on the Protest Reformation to better understand how the religious dimension, mainly the iconoclasm during the Reformation, and the impacts of the different conceptions of religions at that time were perceived by hagiography.
\end{abstract}

Keywords: Religion. History. Reformation. Iconoclasm.

Artigo recebido em 16 set. 2018.

Aprovado em 05 abr. 2019.

\footnotetext{
Doutorando em História pela Universidade Federal Rural do Rio de Janeiro (UFRRJ). E-mail: jglhistoria@hotmail.com. O presente trabalho foi realizado com apoio da Coordenação de Aperfeiçoamento de Pessoal de Nível Superior - Brasil (CAPES) - Código de financiamento 001.
} 


\section{Introdução}

Nos mais arcaicos níveis de cultura, viver como ser humano é em si um ato religioso, pois a alimentação, a vida sexual e o trabalho têm um valor sacramental. Em outras palavras, ser - ou, antes, tornar-se - um homem significa ser 'religioso' (Eliade, 2010, p. 13)

Notadamente um dos maiores nomes da escola fenomenológica, também chamada por alguns autores de escola de Chicago (Gomes, 2002, p. 15), Mircea Eliade busca o Homo religiosus apresentando uma tipologia das formas religiosas de caráter descritivo $e$ paradigmático. Trata-se de uma busca pela "essência" da religião e, tal como podemos apreender da citação acima, do próprio ser humano. Essa perceptiva essencialista e essencializante acerca da religião pode conduzir a compreensão desta última como categoria autônoma do conhecimento, isto é, que pode ser apreendida em si mesma. Mais que isto, pode conferir ao religioso uma especificidade epistemológica, ou então, caso se adote uma abordagem confessional, uma especificidade ontológica. Dessa forma, ainda hoje pode-se constatar abordagens acadêmicas que identificam na religião uma autonomia capaz de forjar uma disciplina independente, isto é, que não está subordinada a outras áreas como a cultura.

Nesse sentido, o presente artigo, divide-se em duas partes. Num primeiro momento, a partir de diferentes perspectivas e abordagens, pretende-se refletir acerca da especificidade (ou não) da História das Religióes como disciplina acadêmica, bem como a autonomia do religioso. Já na segunda parte, mediante revisão bibliográfica sobre a Reforma Protestante, almeja-se verificar os impactos que as diversas maneiras de tratar o religioso (esboçadas no primeiro momento) influenciaram a compreensão sobre a Reforma.

\section{Autonomia, especificidade ou subordinação?}

A História religiosa ${ }^{1}$ é oriunda da História das Religiões que nasce no século XIX como ramo emancipado da Ciência das Religiões (Religionswissenchaft em alemão). Enquanto a segunda (Ciência das Religiões) preocupa-se em analisar a religião em si tomando-a como um substantivo, a História das Religiões analisa o desenvolvimento, bem como a mudança histórica das religiões em diversas épocas, territórios etc. (Gomes, 2002).

Ainda no século XIX, a História das religiões interessava-se pela origem das crenças $e$ ideias religiosas ${ }^{2}$. Valendo-se da etnologia, tais estudos buscavam encontrar a origem da religião 
(neste caso, tomando-a no singular). Já no século XX, sobretudo a partir das obras de Durkheim e Weber, a experiência eclesial era realizada a partir das ciências sociais não mais como um projeto salvífico, mas sim uma elaboração histórico-cultural. No bojo desta transformação a história teológica das igrejas cristãs foi amplamente criticada pela particularidade de suas operações narrativas, consideradas ultrapassadas (e por que não desonestas), por uma historiografia pretensamente científica. Com isto, considerou-se

[...] a formulação de uma historiografia religiosa de cunho científico, o conhecimento histórico também procedeu, em paralelo, a uma desconstrução teórico-metodológica da história teológica das igrejas cristãs. Esta espécie de suspeição acadêmica embasava-se numa dupla refutação: à premissa transcendental ou metafísica da história teológica, bem como ao questionamento do perfil ético-político assumido por parcela das igrejas cristãs e que fora projetado na narrativa dessa mesma história. [...] Em resumo, a história teológica das igrejas cristãs foi considerada eminentemente conservadora (Buarque, 2008, p. 57).

Muitas foram às críticas feitas à historiografia religiosa. De maneira geral, pontuava-se a valorização de uma perspectiva de longa duração em detrimento das rupturas; uma leitura providencialista quase hagiográfica; o tratamento restrito às fontes entendendo o registro documental como "prova comprobatória" e, por fim; a forte veiculação institucional/confessional com a pesquisa, isto é, a perspectiva de que mesmo o pesquisador dominando uma metodologia crítica, se este não estiver comprometido com a fé cristã, não estará habilitado para estudar a história da igreja ${ }^{3}$.

Segundo Virgínia Buarque, no entanto, tais críticas vêm sofrendo uma revisão, sobretudo, a partir das duas últimas décadas do século XX. Categorias como as de cristandade têm sido pensadas despojadas de um perfil monolítico, em prol de uma leitura mais complexa das instituições eclesiais, bem como, a consideração de sentidos atribuídos a tais instituições por seus próprios membros. Apesar disso, a autora aponta que mesmo esta leitura complexificada ainda não abarca a especificidade do religioso.

Ao analisar estudos consagrados em território nacional acerca da experiência religiosa, notadamente os estudos de Roque Spencer de Barros e Luis Mott, Buarque observou que estes, a despeito de incorporarem um viés antropológico, mantiveram-se reducionista no que se refere ao religioso associando-o monoliticamente a preconceitos, superstições e até mesmo fetiches sexuais. De fato, soa demasiadamente pretensiosa (para não dizer, agora em outro contexto, desonesta) a conclusão de Mott acerca das motivações e consequências que levavam católicos a se dedicaram a vida mística (Mott, 1997, p. 174). Sendo assim, Buarque propõe "reconstruir algumas das interfaces, tão tensionais quanto criativas, entre as leituras científica e teológica da história das igrejas cristãs" (Buarque, 2008, p. 54). Para tanto, a autora afirma: 
[...] reflexões contemporâneas apontam para a possível contribuição dos estudos teológicos, que favoreceriam uma maior clarificação das terminologias utilizadas pelas diferentes tradições religiosas, possibilitariam a explicitação de pressupostos religiosos implícitos aos discursos analisados pelos pesquisadores do religioso e, mais ainda, suscitariam uma reflexão sobre o sentido da descrença, ocorrente mesmo dentro de espaços eclesiais. Reconhecemos como válidas todas essas assertivas, mas parece-nos que o desafio lançado à historiografia, no tocante à singularização dos sentidos contidos na experiência religiosa (que ultrapassam a dimensão semântica dos textos, embora não prescinda ela), ainda não foi plenamente respondido.

Ora, se nos debruçarmos sobre as publicações teológicas hoje circulantes, verificaremos que, em muitas destas obras, a experiência religiosa foi significada de forma indutiva $e$, mais do que isto, tomando como referência os limites, as ausências, os "aquéns" da realidade histórica. Parece-nos, portanto, ser aí, onde a racionalidade das ciências e das filosofias modernas tende a renunciar à síntese explicativa, frente a tantas incoerências e absurdos que continuamente agridem as referências éticas e culturais norteadoras das relações entre pessoas, grupos e povos, que a hermenêutica teológica oferece à análise historiográfica outra lógica, em afinidade à kénosis de um Deus que se encarna e é crucificado (Buarque, 2008, p. 61).

A aproximação com a teologia, ao levar em consideração os pressupostos desta última, como a kénosis de um Deus encarnado e crucificado, conseguiria compreender de forma mais clara os discursos provenientes do contexto religioso. Nesse sentido, a especificidade do religioso está em sua formulação teológica sobre si próprio a qual influenciaria o texto proveniente desta ou daquela tradição teológica. Sendo assim, Buarque apresenta uma metodologia adequada para analisar o objeto religioso: 1) Parte-se de um enunciado que pode ser entendido como "protocolo de leitura", no caso um texto documental. Este começa a ser entendido como "resquício de uma experiência de fé" configurada em padrão retórico particular. É importante destacar que parte-se de uma enunciação e não de um sistema teórico ou ideológico; 2) Em seguida, realiza-se a interpretação crítica do enunciado, ou seja, reconstrói-se a apropriação feita pela enunciado das diferentes matrizes teológicas do cristianismo (vertente agostiniana, tomista, etc); 3) $\mathrm{O}$ enunciado é ressignificado a partir das matrizes que serviram para constituição dos fundamentos epistêmicos da fé cristã. A experiência religiosa torna-se o ponto nodal entre a trajetória biográfica, instituição eclesial e experiência social. O intuito é discernir o que tornou possível a produção de uma determinada escrita, ou seja, compreender a "economia religiosa" sem a qual o discurso não existiria; 4) Interpreta, por fim, o potencial performativo da experiência religiosa no cruzamento do que foi enunciado para o que foi vivido e descrito na textualidade.

Além de Buarque, autores como Francisco José da Silva Gomes e Sergio da Mata, também defenderam a especificidade da disciplina e a autonomia do Religioso, respectivamente. 
De acordo com Gomes, o crescente processo de secularização teria reduzido a religião ao domínio do privado, submetendo-a à lei da relativização. Desta forma, sua apreensão como objeto de estudo só seria possível enquanto elemento da história social e/ou cultural e os especialistas de História religiosa estariam, apenas, mantendo artificialmente uma história, no fundo, confessional. Para Gomes, tais argumentações, contudo, não retiram a especificidade do religioso. Isso porque:

Como as opiniões religiosas não têm uma incidência unicamente sobre a busca de sentido para a existência, mas a têm igualmente sobre os comportamentos, ordenando toda a vida do homem crente, inclusive suas práticas sociais, as religiões são também lugares relevantes dos conflitos sociais. Assim sendo, o campo religioso é simultaneamente lugar, produto e fator ativo daqueles conflitos, e parece-me, pois, legítimo considerar a História religiosa como disciplina específica. Afirmada sua legitimidade, há, não obstante, a necessidade de aclarar o seu objeto (Gomes, 2002, p. 16).

O religioso, portanto, é entendido por Gomes como objeto específico que não pode ser diluído na história econômica ou social (como nas décadas e 60 e 70) ou ainda como se faz na atualidade com a história cultural ou a história das mentalidades. Apesar disso, o autor considera que mediante uma vigilância epistemológica, seja possível aproximar a História religiosa da Histórica cultural (Gomes, 2002, p. 17). Esta última, a época em que o texto foi publicado, era apresentada como tendência entre os historiadores que a encaravam como a "história de amanhã". Segundo Gomes,

Na realidade, a histórica cultural que hoje se produz convêm a um tempo de desencantamento e narcisismo. Na histórica cultural, os nossos contemporâneos pensam poder encontrar respostas satisfatórias para as suas perguntas fundamentais, esperam dela uma abordagem global, pedem-lhe que esclareça o sentido do nosso tempo e da evolução que ela nos trouxe. Está, pois, em jogo a nossa identidade coletiva enquanto humanidade (Gomes, 2002, p. 18).

Esta história cultural que busca articular leituras plurais sobre a maneira de crer, esperar, valorar, sonhar etc., em realidade, não é tão novidade assim se pensarmos nos trabalhos de Marc Bloch e Lucien Febvre. De toda forma, um ponto importante a ser destacado é que a relação entre História religiosa e História cultural são complexas. Por um lado, há historiadores que desejam englobar a primeira na segunda, por outro, há aqueles que tendem à distinção dos dois campos tanto por questões epistemológicas quanto institucionais. Para o autor, o mais interessante parece ser a abordagem de uma Nova História religiosa que ao mesmo tempo postula uma nítida distinção entre os dois campos e a inequívoca articulação. Em outras palavras, são campos distintos, e por isso, específicos, contudo, podem ser aproximados ${ }^{4}$. 
No que se refere à História das religiões apresentada por Sérgio da Mata, esta aparece afastada das pretensões tanto apologéticas, quanto desmistificadoras. O que ela pretende é "compreender e explicar geneticamente a religião nas suas relações com a cultura e a sociedade" (Da Mata, 2010, p. 17). Há um esforço consciente em se abster de "juízos de valor" (ou de fé) na construção do conhecimento. A História das religiões, portanto, não é "religiosa" na medida em que seu estudo não pode ser pautado pelos termos do discurso que a religião elabora sobre si mesma. A teologia, consequentemente, não se enquadra na História das religiões, pois não pertence ao campo das "ciências da realidade", visto que seus procedimentos são especulativos e metafísicos. No entanto, a teologia permanece importante para o historiador das religiões na medida em que ela possibilita conhecer o discurso que a religião elabora sobre si própria (Da Mata, 2010, p. 65).

Em síntese, a História das religiões, para Sérgio da Mata, é autônoma como disciplina; multicultural na percepção do objeto, isto é, não deve instituir centralidade no cristianismo e/ou da cultura ocidental; e agnóstica em sua abordagem (Da Mata, 2010, p. 20). Em relação ao primeiro ponto (autonomia da disciplina) não nos parece claro as razões para tal afirmativa. Inferimos que tal justificativa se dê por dois motivos que podemos apreender no trecho abaixo:

Muitos historiadores que se interessam pela relação entre religião e história ignoram a longa e rica tradição de estudos que todo um conjunto de disciplinas - não só as que foram mencionadas - devota ao fenômeno religioso. Seguindo um raciocínio que lembra o do Dr. Vergerus de Bergman, é como se apenas as expressões 'concretas' (políticas, econômicas, sociais) da religião contassem para esses pesquisadores, sem que qualquer atenção tivesse de ser dada àquilo que antecede e subjaz a tais manifestações 'concretas', ou seja: as ideias religiosas propriamente ditas. Para os que comungam de reducionismo desta espécie, as páginas que se seguem nada têm a acrescentar (Da Mata, 2010, p. 20).

O primeiro motivo para tal autonomia, se refere à filiação histórica da disciplina. Em outros termos, a História das religiões origina-se a partir da História eclesiástica, de caráter confessional. Ou seja, ainda que numa perspectiva completamente oposta à História eclesiástica, é por meio e a partir dela que a História das religiões nasce. Vai ser nas tensões e enfretamentos com esta antiga disciplina (por muito tempo tida como autônoma) que surge a "nova" disciplina pensando a religião no plural. Em segundo lugar, acreditamos que Da Mata afirma tal autonomia por considerar as "ideais religiosas", enquanto categoria antecedente a "manifestações concretas", como definidora da religião, isto é, a religião como "força mobilizadora" ${ }^{5}$. Por esta razão, ele afirma:

A religião é expressão inextinguível da conditio humana, deste entrecruzamento entre natureza e cultural [...] que nos constitui e que determina nossos limites 
como seres humanos. Na acepção lata aqui empregada, pode-se afirmar que a religião nunca é efetivamente 'abandonada' por um indivíduo. Ele apenas a substitui por nova forma social de religião.

Exemplos: O culto a um dado herói intelectual (com o sem a constituição de 'Igrejas', interpretações 'canônicas', etc) é um tipo de religiosidade que o meio acadêmico conhece particularmente bem [...]. Quando há décadas, Raymond Aron se referiu polemicamente ao marxismo como, Raymond Aron se refreiu polemicamente ao marxismo como 'ópio dos intelectuais', ele estava, de fato, pondo a nu o caráter religioso de dados tipos de filiação ideológica ou intelectual. [...] Tudo isso atesta a persistência da atitude religiosa, mesmo quando se reluta em ver aí uma 'religião' no sentido tradicional (Da Mata, 2010, p. 90).

Acabamos de apresentar três perspectivas, que não obstante suas diferenças percebem no religioso certa autonomia e/ou especificidade. Em relação aos dois primeiros autores (Virgínia Buarque e Francisco Gomes), podemos observar que suas análises partem da religião cristã, enquanto o último (Sergio da Mata) vale-se de conceitos institucionalizados considerando, essencialmente, aspectos religiosos relacionados ao mundo ocidental. Ambos autores na tentativa de não reduzir a religião ao estudo da História Cultural e/ou conferir autonomia/especificidade ao religioso e História das religiões, acabam negligenciando a própria relação da religião com a cultura.

Nesse sentido, talvez seja de relevo fulcral, retornarmos a própria definição de religião. Segundo Marcello Massenzio, a definição da religião diz respeito ao seu uso no plural, ou seja, religiões. O plural representa o traço distintivo e "dignificante" da matéria, pois o olhar históricoreligioso não se volta apenas para uma religião tomando-a como definição por excelência, mas sim, abarcando as mais diversas formações religiosas (Massenzio, 2005, p. 37).

De acordo com Massenzio, este tratamento dado à religião se inicia no momento em que a civilização ocidental se abre para o conhecimento de outras civilizações. A partir da gênese da etnologia vê-se surgir o culturalmente diverso, em outras palavras, o "outro". Desta maneira, umas séries de questões epistemológicas foram sendo postas. No que se refere à religião, Massenzio questiona se: "é suficiente, é apropriada a bagagem conceitual forjada de maneira prevalente em função do cristianismo para o estudo de outros universos religiosos? Ou seria necessário constituir outros quadros de referência?" (Massenzio, 2005, p. 38). No prolongamento dos estudos histórico-antropológicos, o autor aponta para o papel do Ocidente dentro de um cenário cultural tão dilatado e afirma a necessidade de se repensar à luz de tais estudos o problema da religião.

Um grande problema, segundo Ciro Cardoso, para se definir religião é o juízo de valor 6 . A definição, por exemplo, que parte do pressuposto do homo religiosus, isto é, da hipótese (indemonstrável) de que os seres humanos são religiosos em sua totalidade ou por sua natureza 
só é aceitável, segundo Cardoso, em um contexto de discurso religioso, ou seja, teológico. Vale ressaltar, que o autor não atribui à falta de rigor teórico-metodológico e/ou juízo de valor, apenas, aos casos relativos a questões bíblicas/religiosas praticados por militantes confessionais:

Com o que eu disse até aqui, não estou querendo negar os progressos importantes da Ciência da Religião (Religionswissenschaft) em todos os seus aspectos e divisões, desde que começou, no final do século 19, a destacar-se da Teologia. Também é verdade que estou falando de uma diferença de grau em comparação com outros setores da pesquisa em História e ciências humanas, não de natureza. Afinal, ainda me lembro de meu espanto, em 1967, quando de uma viagem ao Brasil Jacques Godechot, eminente professor de Toulouse, quando lhe perguntei, num jantar, que caminhos o haviam conduzido a elaborar a teoria das 'revoluções atlânticas' do final do século 18 e da primeira parte do 19, ao receber a resposta seguinte: ele e o historiador estadunidense Palmer, com tal noção, haviam desejado proporcionar um contexto histórico à O.T.A.N. quando esta estava sendo organizada após a Segunda Guerra Mundial! Mas continuo achando que há um je ne sais quoi de diferente quando a assunto tem a ver com algumas religiões ainda vivas, num contexto em que os autores e outras pessoas se importem com ela, mesmo em comparação com assuntos atinentes a paixões político-ideológicas candentes, por exemplo (Cardoso, 2005, 2010) (grifo nosso)

A participação de "crentes" nas pesquisas das ciências humanas, sobretudo, em história, para Cardoso, está relacionada, também, ao (suposto) pós-modernismo da História Cultural:

Em tempos pós-modernos, da História Cultural, a crença em não haver verdades, só versões (perspectivismo hermenêutico), ao mesmo tempo desvaloriza as militâncias - os pós-modernos deparam-se 'com o antigo problema dos céticos acerca de como pensar e agir à luz de sua própria doutrina' - e, em nome do suposto caráter subjetivo do trabalho do historiador, leva a reivindicar a possível validade de uma História Religiosa feita por crentes. Esta apresentaria tanto vantagens quanto desvantagens $e$, no caso do historiador crente, exigiria maior vigilância no sentido de garantir pelo menos um relativo distanciamento acadêmico do objeto, para, assim, evitar juízo de valor, hierarquizações indevidas do ortodoxo e do heterodoxo, bom como outras distorções (Cardoso, 2005, p. 222).

Apesar disso, o autor acrescenta, numa espécie de "vai e vem acadêmico", as colocações de Francisco Gosmes, ais quais afirmam que não é, necessariamente, o historiador não crente que conseguirá produzir uma pesquisa mais objetiva e neutra acerca do religioso (Gomes, 2002, p. 20-21). Nos parece que, a despeito de todo esforço e rigor acadêmico que Cardoso procura apresentar em sua análise, no limite, ele não consegue escapar de um "entusiasmo militante" (para usar as palavras do próprio autor) às avessas. Ainda assim, como conclusão, ele defende que: "Mais do que no passado, impõe-se hoje com frequência a análise interdisciplinar ou transdisciplinar nos assuntos da História das religiões e da Religiosidade" (Cardoso, 2005, p. 223). 
Nesse sentido, uma perspectiva que nos parece adequada para o tratamento das religiões, é a História das Religiões defendida por Adone Agnolin. A perspectiva teórica apresentada pelo autor parte de uma desobjetivação da religião, na medida em que não almeja atingir a "essência" por trás do "fenômeno", e sim o entendimento da constituição de seu(s) processo(s) histórico(s). Portanto, a religião é abordada em função de uma cultura.

É por isso, inclusive, que a Fenomenologia se utiliza, muitas vezes - justa $e$ significativamente -, da denominação de Ciência da Religião. De fato, ela parte de uma pressuposta objetivação do religioso (que, portanto, permitiria uma incursão científica, como se tratasse de uma ciência natural) que, preexistindo à história (quase à sua dispersão babélica), mantém o pressuposto de uma unidade do religioso (no singular); enquanto isso, a disciplina histórico-religiosa é - portanto, justa e propriamente - uma História das Religiões, na medida em que parte da problemática histórica das diferenças religiosas, indicação de diferentes processos de formação histórica; [...] a Fenomenologia religiosa chega a uma espécie de objetivismo 'ontológico' da sacralidade que compreende o mundo em sua totalidade e é, por si, historicamente não falsificável (Agnolin, 2013, p. 178-179).

Filiando-se a tradição italiana de História das Religiões, Agnolin procurou encarar a religião para além do cristianismo e da sociedade ocidental. A consequência desta reflexão (partilhada por Massenzio) é a revisão a determinados conceitos apontados como "universais" para o religioso, tal como a "magia", "mito", "rito" etc. Tais considerações estão amparadas na proposta de Ernesto De Martino em sua formulação acerca do "etnocentrismo crítico", isto é, o pressuposto de que o acesso ao "outro" passa, antes de mais nada, pelo aprofundamento de conhecimento de seu próprio mundo. Nas palavras de Massenzio: "a descoberta da alteridade é medida pela contínua descoberta de nós mesmos" (Massenzio, 2005, p. 48).

Parece-nos, portanto, inviável a perspectiva de "separação" das religiões de sua arbitrariedade cultural e, por isso mesmo, histórica. A grande questão a ser ponderada, é que o próprio conceito de cultura está intricadamente ligado ao imperativo histórico. Nesse sentido, o conceito de cultura defendido por Clifford Geertz como algo essencialmente semiótico mesurável através de uma ciência interpretativa que ao invés de leis, procura significados, parece adequado. Nas palavras de Geertz,

[...] o conceito de cultura ao qual eu me atenho não possui referentes múltiplos nem ambiguidade alguma fora do comum, segundo me parece: ele denota um padrão de significados transmitido historicamente, incorporado em símbolos, um sistema de concepções herdadas expressas em forma simbólica por meio das quais os homens comunicam, perpetuam e desenvolvem seu conhecimento e suas atividades em relação à vida (Geertz, 2017, p. 66).

Nesse contexto, a religião entra com a 
[...] capacidade de servir, tanto para um indivíduo como para um grupo, de um lado como fonte de concepções gerais, embora diferentes, do mundo, de si próprio e das relações entre elas [...] e de outro, das disposições 'mentais' enraizadas, mas nem por isso menos distintas [...]. A partir dessas funções culturais fluem, por sua vez, as funções social e psicológica.

Os conceitos religiosos espalham-se para além de seus contextos especificamente metafísicos, no sentido de fornecer um arcabouço de ideias gerais em termos das quais pode ser dada uma forma significativa a uma parte da experiência - intelectual, emocional, moral. O cristão vê o movimento nazista contra o pano de fundo da Queda, a qual, embora não explique no sentido causal, coloca-o num sentido moral, cognitivo e até afetivo. [...] um conjunto de crenças religiosas, também representam um polimento no mundo mundano das relações sociais e dos acontecimentos psicológicos. Eles permitem que sejam apreendidos (Geertz, 2017, p. 90).

Para a análise do historiador e da História das religiões, portanto, entendemos a religião como submetida à cultura. Nesse sentido, não existiria uma especificidade epistemológica da disciplina, muito menos uma "autonomia" do religioso. No entanto, ainda assim, pensamos ser a religião "autônoma" não por estar separada ou independente da cultura, mas sim por ser pertencente à cultura e dentro desta apresentar uma especificidade narrativa, social e por isso mesmo, histórica. Resta-nos agora, a partir do caso da Reforma, perceber como as distintas perspectivas apresentadas até o momento encararam este acontecimento.

\section{Reflexões sobre a História das Religiões a partir da Reforma Protestante}

Em seu capítulo sobre a santidade no Dicionário Temático do Ocidente Medieval (2006), Sofia Boesch Gajano realiza um histórico deste conceito. Seu marco inicial são as civilizações antigas, romana e grega especificamente, mas a ênfase está com o advento do culto aos santos pelo cristianismo e o impulso que esta temática recebeu durante o período medieval. O ponto final da explanação se dá, precisamente, com o surgimento da Reforma.

O caso acima serve para ilustrar uma realidade bastante conhecida e propagada. A saber, o "declínio" do culto aos santos com o movimento reformador. Indo além, ele ilustra um traço distintivo deste movimento cujo começo é tradicionalmente atribuído ao frei Martinho Lutero, isto é, a iconoclastia presente na Reforma. Em outras palavras, a partir da Reforma, tanto o culto aos santos, quanto elementos associados a este, como as hagiografias tão presentes no período medieval, sofrerão duríssimas críticas de modo que entre protestantes, tais elementos não estariam presentes. A estes últimos sola scriptura.

Essa compreensão da "iconoclastia da Reforma", no entanto, deve ser matizada e analisada a luz de outros fatores. O texto Tratado das Relíquias de João Calvino, de 1543, é tradicionalmente apresentado pela historiografia como a crítica mais contundente feita durante a 
Reforma aos santos e os elementos a eles associados (as festas, cultos, hagiografias, etc). Ou seja, este tratado é utilizado como principal fonte para corroborar tal iconoclastia. Todavia, analisemos o que ele diz: "O mesmo foi feito com os apóstolos, mártires e outros santos: em vez de meditar na vida desses homens para seguir seu exemplo, as pessoas passaram a aplicar-se à contemplação e ao entesouramento de ossos, túnicas, cinturões, chapéus e quinquilharias semelhantes" (Calvino, 2017, p. 135). Ora, mais que criticar os santos e seus exemplos, Calvino está efetivamente preocupado em corrigir o "engano" das relíquias no que tange à sua autenticidade, bem como capacidade sobrenatural. Ou seja, se tomarmos este caso específico (e emblemático em razão da importância atribuída a este texto), observaremos que a Reforma, no século XVI, não questionava o caráter de exemplaridade das vidas dos santos, mas a veracidade dos relatos e a capacidade de interseção.

Assim, talvez, por isso, que durante a Reforma encontraremos obras como O Livro dos Mártires, publicada pela primeira vez, em Genebra, em 1554, por Jean Crespin (1520-1572) e reeditado pelo autor até 1570, e por seu discípulo, Simon Goulart, até 1619. Esta obra foi consagrada aos protestantes julgados e condenados à morte por heresia. Trata-se, portanto, de uma obra que narra os casos de martírio protestante e que será lida durantes os cultos a fim de relembrar e fortalecer na fé os que estão sendo perseguidos (Cameron, 1996). Ou seja, durante a Reforma, pode-se encontrar obras que tal como as hagiografias medievais apresentavam um projeto exemplar mediante a vida (e a morte) dos seus "santos". Dito de outro modo, esta suposta iconoclastia da Reforma vigente desde seu surgimento, não se confirma em um exame mais atento das fontes. Finalmente, se por um lado, rechaçava-se a ideia de interseção $e$ manifestação sobrenatural dos santos, seu papel enquanto figura exemplar foi mantido.

Desta maneira, a grande questão a ser posta e que dialoga com os propósitos deste trabalho é: por que se atribuiu à Reforma esta "natureza" iconoclasta? Isto é, por que se tomou a recusa peremptória aos santos e todo e qualquer elemento a estes como parte essencial $e$ constitutiva da Reforma? Acreditamos que as respostas para tais indagações encontram-se intimamente relacionadas com à produção acadêmica acerca do fenômeno Reforma, bem como a perspectiva que se tem encarado os acontecimentos religiosos a qual rejeita, ou melhor, "descola" o religioso de sua arbitrariedade cultural. Tomando-o, portanto, como autônomo e/ou específico.

Carter Lindberg afirma que até recentemente a seleção dos dados que todo historiador faz ao estudar a Reforma era determinada por compromissos religiosos e teológicos. Foi assim porque havia uma dependência aos estudos dos historiadores da Igreja com uma dupla perspectiva: a história da Igreja e a medida crítica de sua fidelidade com uma perspectiva contemporânea do passado (Lindberg, 2017, p. 27). Nesse sentido, o foco destes estudos dá-se 
sob a ótica teológica, ou seja, concentra-se na história de uma comunidade existente, porém inacabada, a Igreja reformada.

Já durante o século XVI, desenvolveu-se uma historiografia protestante amplamente amparada no modelo historiográfico da História Eclesiástica de Eusébio de Cesareia ${ }^{7}$. Os Reformadores sustentam esse modelo ao se reivindicarem como continuação da igreja primitiva, sobretudo em razão do apelo à Escritura e à fé apostólica. O maior exemplo dessa historiografia da Reforma vai ser as Centúrias de Magdeburgo. Sob a liderança do luterano Matthias Flacius Illyricus, a obra chamava-se Historia Ecclesiae Christi e narrava a história da Igreja desde a origem do cristianismo. Por estar dividida em séculos e ter sido redigida na cidade de Magdeburgo, a obra ficou conhecida pelo nome de "Centúrias...". Esta obra dividia a história em 3 períodos: da época dos apóstolos até o ano 600 mantinha-se a pureza original da Igreja; de 600 até o século XV o poder do Papado aumenta conjuntamente com a decadência da Igreja; por fim, a partir do século XVI tem-se o novo período de recuperação do evangelho. $\mathrm{O}$ interessante de se observar nesta estruturação é que até hoje tal perspectiva pode ser encontrada em obras vinculadas ao que podemos caracterizar como uma historiografia confessional que, apesar de se pretender "imparcial", acaba negligenciando acontecimentos/processos históricos constitutivos da própria Reforma.

Tal é o caso de Earle Cairns, em $O$ cristianismo através dos séculos ${ }^{8}$. Justificando seu trabalho como historiador, Cairns apresenta as diferentes definições do que, para ele, seria "história". Desta maneira o autor sintetiza:

[...] história pode ser evento ou acontecimento, pesquisa ou processo $e$ produto, ou interpretação. A história, como evento, é absoluta, ocorrendo somente uma vez no tempo e espaço; mas história como informação, pesquisas e interpretação, é relativa e sujeita a mudança. A história pode ser definida como relato interpretado do passado humano socialmente importante, baseado em dados organizados e reunidos pelo método científico a partir de fontes arqueológicas, literárias ou vivas. O historiador da Igreja deve ser tão imparcial na coleta de dados da história quanto o historiador secular, muito embora reconheça que ninguém pode ser neutro diante dos dados, uma vez que cada um tratará do material com uma estrutura própria de interpretação (Cairns, 1995, p. 14).

O autor admite, portanto, uma divergência entre a produção historiográfica do "historiador secular" para o "historiador da Igreja" (notadamente confessional). Para Cairns, apesar do uso da metodologia científica atrelado ao recolhimento imparcial das fontes históricas pelos historiadores (seculares e da Igreja), a história permanece com uma dimensão interpretativa. Assim, cabe ao historiador protestante da Igreja interpretar essa história mediante 
a consideração das ações de Deus no tempo e no espaço 9 . Por consequência, afirma o autor acerca da história protestante da Igreja:

Ela é a história interpretada e organizada da redenção do homem e da terra. Somente se esta definição for observada é que o estudante cristão de história poderá fazer um relato cuidadoso da história da Fé que ele professa. Neste ponto, os filhos da luz não podem ficar atrás dos filhos das trevas. Deus é transcendente em relação à criação, mas imanente na história da redenção (Cairns, 1995, p. 14)

Fica evidente, portanto, que a produção de História para os historiadores confessionais da Igreja, tal como Cairns a entende, é um embate entre os "filhos da luz" contra os "filhos das trevas". Como afirma o autor doravante, deve-se fazer história para encontrar a glória de Deus, porque: "a história torna-se um processo de conflito entre o bem e o mal, entre Deus e o Diabo, no qual o homem não tem qualquer esperança fora da graça de Deus" (Cairns, 1995, p. 16).

Sendo assim, a perspectiva defendia por essa historiografia confessional da Igreja vai apresentar a Reforma como um evento teleológico e escatológico, essencialmente religioso e moral. Ou seja, a Reforma é encarada como inevitável e ocasionada, principalmente, pela decadência moral da Igreja Romana. Todos os demais fatores levados em consideração, como o político, o econômico, o social e o cultural são secundários sob esta perspectiva. Além disso, a Reforma é tomada como um movimento de retorno legítimo e fiel ao Novo Testamento e não como um movimento original, isto é, que criava algo novo na história (Cairns, 1995, p. 221231).

Outra abordagem aplicada a Reforma é a veiculada aos estudos marxistas. Segundo Delumeau (1989, p. 251), desde o nascimento do Marxismo, uma causa exclusivamente econômica tentava explicar a Reforma - ela estava a serviço de causas estritamente econômicas/materiais e a dimensão religiosa era apenas uma capa utilizada para dissimular os verdadeiros interesses das classes envolvidas. Nas análises, portanto, as questões teológicas são negligenciadas e a Reforma é apresentada como "filha" de uma nova economia que viria a se impor, a saber: o capitalismo.

Uma figura importante que receberá atenção dos marxistas, inclusive pelo próprio Engels, será Thomas Müntzer, chefe da revolta camponesa, morto em 1525. Müntzer, bem como a revolta por ele liderada, aparecem como a "reforma plebeia", precursora do socialismo, em oposição à "reforma burguesa" levada a cabo por Lutero ${ }^{10}$. A guerra dos camponeses aparecia, portanto, como a primeira revolução social importante, no momento em que antecede o capitalismo, que a Europa conheceu. 
Na década de 1960, Delumeau publica sua obra Nascimento e afirmação da reforma na qual critica tanto a abordagem dos historiadores da Igreja e teólogos, que atribuem a Reforma aos desvios morais, quanto aos marxistas $e$ historiadores sociais que supervalorizam $o$ econômico e/ou o social (como o surgimento dos Estados-nacionais, crescimento do pensamento humanista e a valorização do indivíduo) e negligenciam o religioso. Para o autor, a principal chave explicativa encontra-se no fator religioso, isso porque, "nem a filosofia, nem a sociologia, nem o nacionalismo, nem a economia podem explicar Lutero, mas apenas a religião" (Delumeau, 1989, p. 269). Aqui Delumeau não apresenta a religião desconectada da história, mas como produtora de mentalidade e, por consequência, realizadora e produto de mudanças sociais.

Nesse sentido, Delumeau identifica a ênfase que o Protestantismo confere a três doutrinas principais: a justificação pela fé, o sacerdócio universal e a infalibilidade da Bíblia, que respondiam às necessidades religiosas do seu tempo (como a angústia coletiva sedimentada cada vez mais pela ideia de pecado como provedor da danação eterna), sem as quais a Reforma não teria conhecido o sucesso que conheceu. Desta maneira, o autor é muito eficaz ao historicizar o surgimento da teologia da Reforma, ao contrário de autores como Cairns. Contudo, Delumeau supõe uma ruptura muito imediata com as práticas da Igreja romana, como o culto aos santos e a escrita hagiográfica. Podemos dizer que Lindberg, em publicação mais recente, também adotou a linha interpretativa do historiador francês (a religião e a teologia como horizontes fundamentais), mas também supondo esta ruptura imediata.

No que toca este trabalho, concordamos com os dois últimos autores ao se atribuir maior importância às questões religiosas e teológicas para o estudo da Reforma ${ }^{11}$. Contudo, ao contrário deles, subordinamos tais questões a uma abordagem da História das Religiões (como fora apresentada na primeira parte deste artigo), a qual rejeita qualquer interpretação essencialista e/ou fenomenológica da religião, bem como uma autonomia e/ou especificidade do religioso em relação à cultura tal como realizou Delumeau, Lindberg, Cairns, entre outros ${ }^{12}$. Ora, ao partir da ideia de que existia uma "teologia da Reforma", tais autores atribuíram à Reforma uma essência teológica que derivava em iconoclastia, ou seja, em recusa peremptória ao culto aos santos e toda associação possível.

A grande questão é que ao abordarem a religião e a teologia da Reforma sob a perspectiva supracitada (essencialista e/ou fenomenológica, desvinculada da cultura), tais autores negligenciaram a possibilidade de pensar obras como o Livro dos Mártires mediante a perspectiva de uma santidade protestante que, ao registrar tais eventos, acabava produzindo relatos hagiográficos sobre seus "santos" ${ }^{3}$. Nesse sentido, entendemos ser profícuo submeter à própria ideia da santidade protestante ao escrutínio das práticas envolvidas nos processos 
históricos da Reforma, observando tanto continuidades (uma escrita hagiográfica protestante) quanto rupturas (a recusa da ideia de intercessão).

\section{Conclusão}

A partir do que foi apresentado, afirmamos ter demonstrado os problemas em se pensar a religião como categoria autônoma e/ou específica para além de sua relação com a cultura. Tomando como exemplo a Reforma, verificamos que tais perspectivas, ainda que diversas, acabaram por essencializar tal acontecimento tomando aprioristicamente como "iconoclasta". Ora, esta perspectiva é facilmente absorvida quando se entende a religião descolada de sua arbitrariedade cultural e histórica. Porém, se pensarmos a religião nos termos de uma História das Religiões tal como apresentada neste trabalho, conseguimos matizar esta suposta iconoclastia percebendo que sua presença está mais nas disputas discursivas e teológicas do que nas práticas sociais. Ou então que sua consolidação se deu de maneira processual e não abrupta $e$ instantaneamente.

Eliade, talvez, realmente esteja certo ao dizer que viver como ser-humano é um ato religioso, posto que por ser religioso é cultural e por ser cultural é histórico e, por isso mesmo, humano. A religião, portanto, não poderia ser melhor local para o historiador. Finalmente, como nos lembra Marc Bloch, o objeto da história é, por natureza, a humanidade e o bom historiador é aquele que tal como o ogro da lenda sabe que onde está a carne humana, está sua refeição (Bloch, 2002).

\section{Referências}

AGNOLIN, Adone. História das Religiões: perspectiva histórico-comparativa. São Paulo: Paulinas, 2013.

BLOCH, Marc. Apologia da História ou o ofício do historiador. Rio de Janeiro: Zahar, 2002.

BUARQUE, Virgínia A. Castro. A especificidade do religioso: um diálogo entre historiografia e teologia. Projeto História, São Paulo, n. 37, dez. 2008, p. 53-64.

CAIRNS, Earle E. O Cristianismo através dos séculos: uma história da Igreja cristã. 2 ed. São Paulo: Vida Nova, 1995.

CALVINO, João. Tratado das Relíquias (1543). In. Uma coletânea de escritos. São Paulo: Vida Nova, 2017.

CAMERON, Pierre. Le martyrologe de Jean Crespin, étude de ses éditions au XVIe siècle. Tese (Ph.D. en études classiques et médiévales). 443f. Université de Montréal, 1996.

CARDOSO. Ciro. História das Religiões. In: Um historiador fala de teoria e metodologia: ensaios. Bauru, SP: Edusc, 2005, p. 209-210. 
DELUMEAU, Jean. Nascimento e afirmação da Reforma. São Paulo: Pioneira, 1989.

ELIADE, Mircea. História das crenças e das ideias religiosas, volume I: da Idade da Pedra aos mistérios de Elêusis. Rio de Janeiro: Zahar, 2010.

GAJANO, Sofia Boesch. Santidade. In: LE GOFF, Jacques e SCHMITT, Jean-Claude. Dicionário temático do Ocidente medieval. Vol. II. Bauru/São Paulo: EDUSC/Imprensa Oficial, 2006, p. 449-463.

GEERTZ, Cliford. A interpretação das culturas. Rio de Janeiro: LTC, 2017.

GOMES, Francisco José Silva. A religião como objeto da História. In: LIMA, Lana L. a Gama et alli. História \& Religião. Rio de Janeiro: Mauad, 2002, p. 13-24.

LINDBERG, Carter. História da Reforma. Rio de Janeiro: Thomas Nelson, 2017.

MASSENZIO, Marcello. A história das religiões na cultura moderna. São Paulo: Hedra, 2005.

MATA, Sérgio da. História \& Religião. Belo Horizonte: Autêntica, 2010.

MOTT, Luiz. Cotidiano e vivência religiosa: entre a capela e o calundu. In: SOUZA, Laura de Mello e (org.). História da vida privada no Brasil, vol. 1: Cotidiano e vida privada na América portuguesa. São Paulo: Cia. das Letras, 1997, p. 155-220.

\footnotetext{
${ }^{1}$ Francisco José da Silva Gomes trata como "História religiosa" aquilo que remete para as ciências humanas e sociais, enquanto História da Religião ou das Religiões para o discurso histórico propriamente dito.

${ }^{2}$ Não é propósito deste artigo traçar um "histórico" da História das Religiões. Para este fim, recomenda-se o artigo de Bellotti, 2011. Bem como o livro de Mata, 2010.

${ }^{3}$ Estas críticas podem ser encontradas no trabalho de Virgínia Buarque utilizado neste artigo.

${ }^{4}$ Provavelmente um dos melhores exemplos desta historiografia religiosa defendida por Gomes, seja o trabalho do grande medievalista francês, André Vauchez. A guisa de exemplo, em seu livro A espiritualidade na Idade Média Ocidental, Vauchez oferece um exemplo do que seria esta História religiosa ao utilizar o conceito de espiritualidade. Tomando tal conceito como uma relação existente entre certos aspectos do mistério cristão e práticas como ritos, preces e devoções presentes no interior da vida cristã, o autor demonstra como tal relação, por mais "mística" que fosse, isto é, afeita aos mistérios da fé, não deixou de ser vivida por pessoas historicamente determinadas e que por esta mesma razão, também determinaram historicamente a espiritualidade. Cf. Vauchez, 1995. Vale destacar que os trabalhos de Jean Delumeau, cuja obra referente a Reforma será analisada neste artigo, também pode ser enquadrado entre os autores desta "História religiosa".

${ }^{5}$ A este respeito ver a exposição que o autor faz acerca do stalinismo como produtor de um mito. Cf. Da Mata, p.81.

${ }^{6}$ No limite, o que Cardoso está discutindo é o "quem" pode ou não estudar a religião.

${ }^{7}$ Para maiores informações acerca desta relação entre a História Eclesiástica de Eusébio e a historiografia da Reforma: Cf. (Lindberg, 2017). Em relação à obra do bispo palestino Eusébio de Cesáreia no que se refere à composição da própria historicidade da sua obra: cf. Almeida; Torre, 2015, p. 9-35.

${ }^{8}$ Até 1981, esta obra já havia sido reeditada mais de 20 vezes. Até 1995, já se encontrava, no Brasil, cerca de 2 edições e 3 reimpressões. Em 2008 a Editora Vida Nova, importante divulgadora de obras confessionais protestantes, reeditou, mais uma vez, a obra de Cairns. Para maiores informações: http://vidanova.com.br/211-cristianismo-atravesseculos.html

9 Aqui, por exemplo, o leitor poderá observar nitidamente uma das críticas apresentadas acima por parte da historiografia "científica" à historiografia confessional. Ou seja, que para a historiografia confessional, apenas os que professam a confissão estão habilitados para realizar tais estudos. Curiosamente, como demostramos também na primeira cessão, o oposto também se mostrou verdadeiro, isto é, a crítica por parte da historiografia "científica" de que "crentes" não poderiam falar sobre religião em razão do seu envolvimento. Ao que parece, pelo menos em boa parte da academia, esta ideia encontra-se superada.

${ }^{10} \mathrm{O}$ livro de Ernest Bloch, no Brasil, é um dos principais a apresentar esta abordagem. Cf. Bloch, 1973, p. 206.

${ }^{11} \mathrm{Na}$ realidade, o mais correto a ser dito não é "atribuir maior importância às questões teológicas e religiosas", porém compreender que no período analisado, é simplesmente impossível descolar o que se entende atualmente como "religião" de outros setores como a política, economia, etc. A este respeito verificar: Scatolla, 2009.
} 
${ }^{12}$ Este será o caso de reconhecidos pesquisadores como: Bernard Cottret e Francis Higman (2010). Cf. Higman (2001).

${ }^{13}$ Isso explica os limites cronológicos do capítulo sobre a "santidade" de Sofia Boesch Gajano que inicia esta sessão. 